\title{
Uroperitônio secundário à nefrite intersticial em bovinos - relato de dois casos
}

Ângela Imperiano da Conceição $0^{[a] ", ~ L a i ́ s ~ R e s e n d e ~ P a u l i n o ~}{ }^{[a]}$, Carla Lopes de Mendonçą[b] José Augusto Bastos Afonso ${ }^{[b]}$, Nivaldo de Azevedo Costa, Nivan Antônio Alves da Silva ${ }^{[b]}$, Rodolfo José Cavalcanti Souto ${ }^{[b]}$, Maria Isabel de Souza ${ }^{[b]}$, Luiz Teles Coutinho[b], Jobson Filipe de Paula Cajueiro[b]

\footnotetext{
[a] Programa de Residência em Sanidade de Ruminantes, Clínica de Bovinos, Universidade Federal Rural de Pernambuco (UFRPE), Garanhuns, PE, Brasil

[b] Clínica de Bovinos, Universidade Federal Rural de Pernambuco (UFRPE), Garanhuns, PE, Brasil
}

*Autor correspondente

e-mail: angelaimperiano@hotmail.com

\section{Resumo}

Uroperitônio ocorre de forma secundária à lesão do trato urinário, que leva ao extravasamento da urina para a cavidade abdominal, e clinicamente caracteriza-se por deterioração do estado geral do paciente, apatia, anorexia, disúria, polaquiúria, taquicardia, taquipnéia, abdome distendido e ascite. 0 diagnóstico se estabelece pela abdominocentese e posterior determinação do teor da creatinina e/ou uréia no líquido peritoneal ou através de achados necroscópicos. A ultrassonografia transabdominal constitui ferramenta importante para o diagnóstico de ascite, porém não define a natureza do líquido. Relatos de casos de uroperitônio em bovinos são ainda escassos na literatura. Por este motivo, são relatados dois casos desta enfermidade em vacas, que foram atendidas na Clínica de Bovinos, Campus Garanhuns, Universidade Federal Rural de Pernambuco (CBG/UFRPE). O histórico do animal um (A1) foi de cólicas, contrações abdominais, fezes escuras e em pequena quantidade. 0 animal dois (A2) apresentava alterações nas fezes, como o anterior, além de timpanismo ruminal recidivante. 0 exame clínico revelou apatia, anorexia, desidratação, taquicardia, acentuada distensão abdominal e marcada hipomotilidade do sistema digestório. Na palpação retal do A1 constatou-se estrutura firme no quadrante superior da fossa paralombar direita, próximo ao rim, e no A2, a palpação foi limitada devido a um estreitamento do lúmen. A análise do fluído ruminal de ambas as vacas evidenciou comprometimento dos infusórios e elevação nos teores de cloretos (A1 38,71 mEq/L e A2 62,97 mEq/L); e no A1, a redução do azul de metileno foi retardada. 0 hemograma de ambos revelou hiperfibrinogenemia e desvio à esquerda regenerativo na leucometria, entretanto, apenas o A1 apresentava leucocitose. Os achados ultrassonográficos sugeriram ascite, indícios de peritonite (fibrina) e de comprometimento renal (rins com imagem pouco definida e reduzidos de tamanho). A análise do líquido 
peritoneal dos dois animais revelou níveis elevados de creatinina (A1 16,04mg/dL e A2 6,96 md/dL). Tais achados definiram o diagnóstico de uroperitônio. Com o prognóstico desfavorável, foram autorizados o sacrifício e necropsia dos animais. Nos exames anatomopatológicos, constatou-se grande quantidade de líquido no peritônio ( \pm 150 litros), de cor avermelhada, pouco turvo, com material filamentoso e friável (fibrina), aderido de forma multifocal ao peritônio parietal e superfície dos órgãos abdominais. Os rins do A1 apresentavam-se aumentados, cápsula excessivamente aderida, abscessos multifocais na zona cortical, áreas de hemorragia, infarto e necrose por onde drenava conteúdo urinário, além de hidronefrose secundária a cálculos, coágulos sanguíneos e exsudato fibrino-necrótico presentes no lúmen dos ureteres. Os rins do A2 estavam reduzidos de tamanho, com consistência aumentada, redução do padrão lobular, zona cortical de cor amarelo-alaranjado e zona medular de coloração próxima ao normal. Sendo assim, o quadro de uroperitônio e peritonite sero-fibrinosa foi consequente à nefrite intersticial crônica difusa bilateral e, ainda, urolitíase obstrutiva (A1). 